\title{
Fractionation of DNA isolated from lymphocytes of patients under therapy with the antiblastic drug cis-diamminedichloroplatinum(II) using pulsed field gel electrophoresis
}

\author{
Paweł Jaruga $^{1_{*}}$, Tomasz H. Zastawny ${ }^{1}$, Jerzy Tujakowski ${ }^{2}$ and Ryszard Oliński ${ }^{1}$ \\ ${ }^{1}$ Department of Clinical Biochemistry, Medical Academy of Bydgoszcz, M. Curie-Skłodowskiej 9, 85-094 \\ Bydgoszcz, Poland \\ ${ }^{2}$ Provincial Hospital of Bydgoszcz, Clinic of Oncology, Ujejskiego 75, Bydgoszcz, Poland
}

The method known as pulsed-field gel electrophoresis (p.f.g.e.) $)^{1}$ is extensively used for fractionation of large DNA molecules (even over $7 \mathrm{Mbp}$ ) [1 - 6]. P.f.g.e. has numerous applications, such as detecting single and doublestranded breaks, chromosomal mapping of microorganisms, as well as cytogenetic characterization and separation of entire chromosomes.

Here we have applied this method to study changes in the DNA isolated from lymphocytes obtained from cancer patients undergoing cisDDP therapy.

For isolation of the DNA, we used lymphocytes suspensions obtained from 6 lung carcinoma patients. Blood samples $(2 \mathrm{ml})$ were obtained from patients prior to and $24,48,72$ and $120 \mathrm{~h}$ after administration of the drug. The lymphocytes were isolated by centrifugation in a density gradient. Blood was diluted 1:1 using physiological saline solution, then overlayed on Gradisol Land centrifuged for $30 \mathrm{~min}$ at 400 g. The resulting suspension of lymphocytes was mixed with $3 \%$ ultra-low gelling temperature agarose (Sigma, gelling below $15^{\circ} \mathrm{C}$ ) at $30^{\circ} \mathrm{C}$, then immediately put onto $1 \%$ agarose gel (BioRad, DNA grade, size $15 \times 15 \times 0.5 \mathrm{~cm}$ ), containing RNase $(10 \mu \mathrm{g} / \mathrm{ml})$. To release DNA from the cells the gel was incubated overnight in a solution containing $0.5 \mathrm{M}$ EDTA, $2 \% \mathrm{~N}$-lau- royl sarcosine sodium salt and $1 \mathrm{mg} / \mathrm{ml}$ of proteinase $\mathrm{K}, \mathrm{pH} 8.0$, at room temperature [1].

The pulsed field gel electrophoresis was performed in: A, a laboratory made chamber with 24 electrodes positioned in a hexagonal orientation; they produced two homogenous electric fields at an angle of $120^{\circ}$ to one another, forcing the DNA molecules to move in a zig-zag course through the gel (as is shown in Fig. 1) with a net migration along the resulting vector of this fields (c.h.e.f.); and B, in a classical horizontal electrophoresis tank $(15 \times 10 \mathrm{~cm})$ for submarine techniques where two electrodes produced two homogenous and inversed fields. Long pulse time was made with a pulse control unit in the direction of net DNA migration, and short time in reverse direction (f.i.g.e.). Good quality separations were obtained by using $40 \mathrm{~s}$ pulses with the applied voltage of $7 \mathrm{~V} / \mathrm{cm}$, time $40 \mathrm{~h}$ for c.h.e.f. and with pulse time $45 \mathrm{~s} / 15 \mathrm{~s}$ and 10 $\mathrm{V} / \mathrm{cm}$, time $25 \mathrm{~h}$ for f.i.g.e. The running buffer (TBE: $0.089 \mathrm{M}$ Tris, $0.088 \mathrm{M}$ boric acid and 0.002 $M$ EDTA) was cooled $\left(10^{\circ} \mathrm{C}\right)$ and circulated continuously through the unit. Afterwards, the gels were stained with ethidium bromide and photographed.

Cis-DDP is one of the drugs most commonly used in the treatment of human neoplasia. The drug preferentially binds to two neighboring guanine bases and to adenine residues adjacent

*To whom requests for reprints should be addressed

${ }^{1}$ Abbreviations: p.f.g.e., pulsed field gel electrophoresis; cis-DDP, cis-diamminedichloroplatinum(II); c.h.e.f., clamped homogeneous electric field; f.i.g.e., field inversion gel electrophoresis 


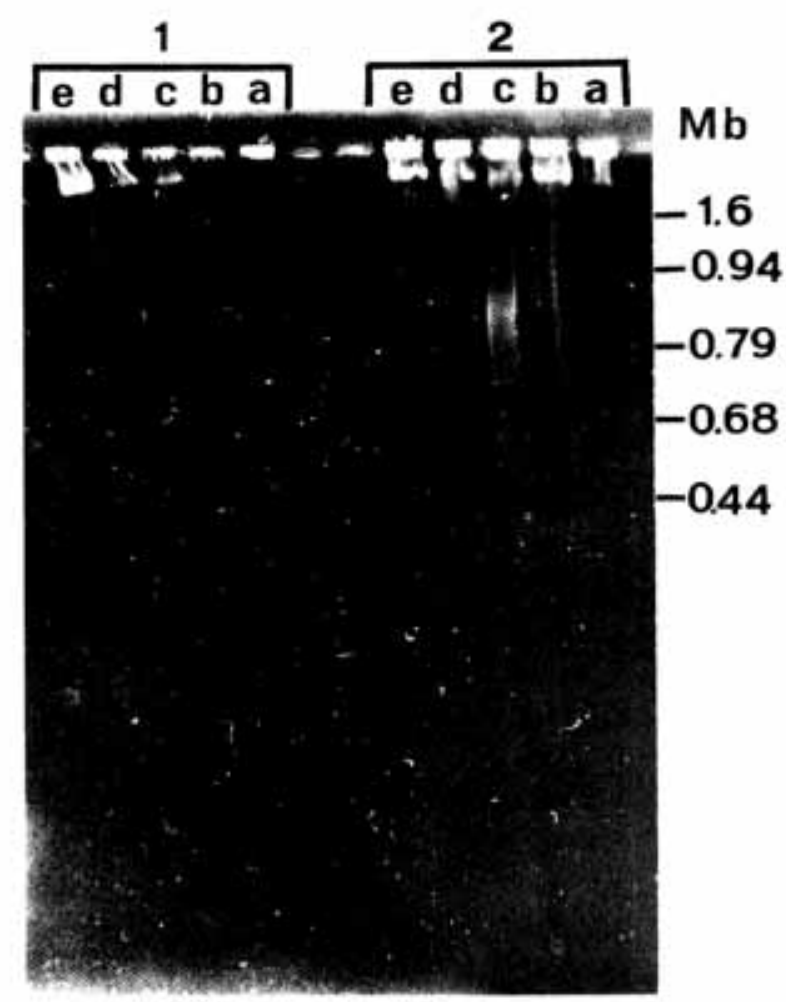

Fig. 1. Pulsed-field gel electrophoresis (c.h.e.f.) of lymphocytes DNA isolated from lung carcinoma patients No. 1 and No. 2 after administration of cis-DDP.

Lanes $1 \mathrm{a}$ and $2 \mathrm{a}$, control (before administration of the drug); lanes $1 \mathrm{~b}$ and $2 \mathrm{~b}$, after $24 \mathrm{~h}$; lanes $1 \mathrm{c}$ and $2 \mathrm{c}$, after 48 $\mathrm{h}$; lanes $1 \mathrm{~d}$ and $2 \mathrm{~d}$, after $72 \mathrm{~h}$; lanes $1 \mathrm{e}$ and $2 \mathrm{e}$, after $120 \mathrm{~h}$

to guanine residues. The formation of these chelates correlates well with antitumor activity [7 - 11].

The photographs shown here illustrate the results of p.f.g.e. of DNA samples from lymphocytes isolated from patients undergoing a cis-DDP therapy. Lanes b, c, $\mathrm{d}$ and $\mathrm{e}$ from series 1 and 2 (Fig. 1) and $3 \mathrm{~d}$ and $\mathrm{e}$ (Fig. 2) suggest a large number of breaks within DNA molecule resulting from administration of the drug. Lane e particularly well shows extensive fragmentation of the DNA $120 \mathrm{~h}$ after administration of the drug.

Cis-DDP does not cause DNA nicks by direct attack [12].

However, many studies suggest that binding of cis-DDP to cellular DNA may cause its local denaturation [11].

The DNA region disturbed by cis-DDP binding might be subject to DNA endonuclease action [13 - 17]. Indeed, some authors observed

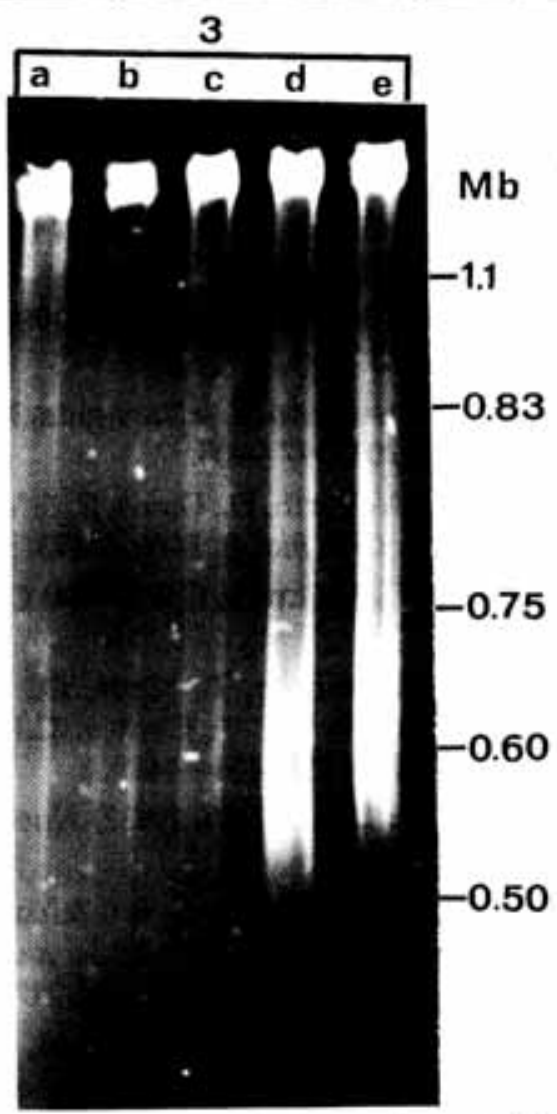

Fig. 2. Pulsed-field gel electrophoresis (f.i.g.e.) of lymphocyte DNA isolated from lung carcinoma patient No. 3 after administration of cis-DDP.

Lane $3 \mathrm{a}$, control (before administration of the drug); lane $3 \mathrm{~b}$, after $24 \mathrm{~h}$; lane $3 \mathrm{c}$, after $48 \mathrm{~h}$; lane 3d, after $72 \mathrm{~h}$; lane $3 e$, after $120 \mathrm{~h}$

DNA double strand breaks resulting from treatment of cells or nuclei with cis-DDP. They believe that the breaks are secondary changes resulting from the excision of crosslinks from DNA strands [13 - 17].

In summary, our study shows for the first time fragmentation of the DNA isolated from lymphocytes of cancer patients receiving cis-DDP chemotherapy.

It seems of interest that one patient responded in a quite different way: DNA isolated from the lymphocytes obtained from this patient was not fragmented at all (data not shown).

Whether the observed effect of cis-DDP therapy correlates with the tumor regression remains to be established. The method applied may enable better monitoring of the patients undergoing chemotherapy. Such monitoring would reduce the risk involved in the application of anticancer drugs. 


\section{REFERENCES}

1. Blocher, D., Einspenner, M. \& Zajackowski, J. (1989) Int. J. Radiat. Biol. 56, 437 - 448.

2. Carle, G.F. \& Olson, M.W. (1984) Nucleic Acids Res. 12, 5647 - 5664.

3. Chu, G., Vollrath, D. \& Davis, R.W. (1986) Science 234, 1582 - 1585.

4. Niwa, O., Matsumoto, T. \& Yanagida, M. (1986) Molec. Genet. 203, 397 - 405.

5. Orbach, M.J., Vollarth, D., Davis, R. \& Yanofsky, C. (1988) Mol. Cell. Biol. 8, 1469 - 1473.

6. Schwartz, D.C. \& Cantor, C.R. (1984) Cell 37, 67 -75 .

7. Smith, C., Matsumoto, T., Niwa, O., Klco, S., Fan, J., Yanagida, M. \& Cantor, C.R. (1987) Nucleic Acids Res. 15, 4481 - 4489.

8. Vollarth, D. \& Davis, R.W. (1987) Nucleic Acids Res. 15, 7865 - 7876.

9. Poirier, M.C., Reed, E., Ozols, R.F. \& Yuspa, S.H. (1986) UCLA Symposium of Molecular and Cellular Biology (Liss, A.R., ed.) vol. 32, pp. 247 - 252.

10. Eastman, A. (1987) Pharmacol. Ther. 34, 155 - 166.

11. Bruhn, S.L., Toney, J.H. \& Lippard, S.J. (1990) Progress in Inorganic Chemistry: Bioinorganic Chemistry (Lippard, S.J., ed.) vol. 38, pp. 477 517.

12. Butour, J.L. \& Macquet, J.P. (1981) Biochim. Biophys. Acta 653, 305 - 315.

13. Cerutti, P.A. (1975) in Molecular Mechanisms for Repair of DNA (Hanawalt, P.C. \& Setlow, R.B., eds.) Part A, pp. 3 - 12, New York, Plenum Press.

14. Paterson, M.C. (1978) in Carcinogenesis: identification and mechanisms of action (Shaw, S.R. \& Griffin, A.C., eds.) pp. 251 - 276, Academic Press, New York.

15. Hannan, M.A., Zimmer, S.G. \& Hazle, J. (1984) Mutation Res. 127, 23 - 30.

16. Oliński, R. (1986) Molec. Biol. Rep. 11, 25 - 28.

17. Bedford, P., Fichtinger-Schepman, A.M.J., Shellard, S.A., Walker, M.C., Masters, J.R.W. \& Hill, B.T. (1988) Cancer Res. 48, 3019 - 3024. 